\title{
The Gender Diversity - Firm Performance Relationship By Industry Type, Working Hours, And Inclusiveness: An Empirical Study Of Japanese Firms
}

\author{
Yukiko Nakagawa, Keio University Economic Research Observatory,Japan
}

\begin{abstract}
This research is unique because it presents empirical evidence testing whether increasing gender diversity is associated with improved firm performance for Japanese listed companies, which have different cultural backgrounds from Western companies, after controlling for size and firm age.

As Worthley et al. (2009) point out, the growing importance of the Japanese female workforce under global competition requires a better understanding of gender-related issues in organizational management which is undergoing a transformation from their rooted traditional managerial habits, such as seniority-based promotion, lifetime employment, paternalism, or prioritizing corporate harmony, which favormen.

We find statistically significant positive relationships between managerial gender diversity and one measure of firm performance, Tobin's q, without a long time lag required for it to be realized.

We find, similarly to Siegel and Kodama (2011), that manufacturing firms benefit significantly and sensitively to a greater extent from increasing managerial gender diversity as compared to those in the service industries, and moreover the curvature of this relationship is significantly greater for manufacturers. Furthermore, firms that demand fewer hours of overtime by their employees also experience this performance boost with increases in management gender diversity, with the same concave shape, and the more OT is reduced the more pronounced is the effect. Having established a committee for diversity promotion by 2006 did not show any impact on firm performance per se, even by 2012, but it did magnify the effect of gender diversity on Tobin's q, providing support for Pless and Maak's (2004) conjecture that a culture of inclusiveness is required for the benefitsaccruing from gender diversity to truly be realized.
\end{abstract}

Keywords: Gender Diversity; Firm Performance; Tobin's q; ManufacturingIndustry; Service Industry; Working Hours; Inclusiveness

\section{INTRODUCTION}

\footnotetext{
(n the World Economic Forum's Gender Gap Index of 2013 Japan ranked 105 out of 136 countries. The index continues to track the strong correlation between a country's gender gap and its national competitiveness, income, and development. A country's competitiveness depends on its human talent - the skills, education and productivity of its workforce (Hausmann et al. 2013). The gender gap is significantly greater in Japan than in any other advanced OECD countries. The weakest indicator for Japan was its low ratio of women managers in firms. ${ }^{1}$
}

${ }^{1}$ See Hausmann, Tyson, and Zahidi (2012). 
While there are several arguments that suggest firms could improve their performance by more actively employing women in managerial roles, empirical studies have yielded mixed results. Though in principle, increases in the female manager ratio do not necessarily imply increasing gender diversity, in practice in Japan, they are synonymous, owing to the very low numbers of women managers. There's also a body of research that suggests that although interactions with those diverse others may initially seem more difficult and effortful than interactions with similar others, they are associated with several benefits (Holoien 2013).

The purpose of this analysis is to explore whether, and to what extent, firms' competitiveness, as Pfeffer (1994) asserts, in the long term depends significantly on their developing equal opportunities regardless of gender. In particular, we study the effect that an increase in the gender diversity of a workforce has on organization-level performance and whether or not such equal opportunity working environments can help to improve Japanese firm performance.

This study was conducted in Japan, where there is a scarcity of studies on the impact of firm performance on managerial gender diversity. In contrast, most western studies have focused on diversity in board membership or employees and have been conducted in countries with much higher rates of female managerial participation than Japan.

This research is unique because it presents empirical evidence testing whether increasing gender diversity is associated with improved firm performance for Japanese listed companies, which have different cultural backgrounds from Western companies, after controlling for size and firm age.

Moreover, we examine the curvature of these relationships to estimate the moderating effect of industry type on the gender diversity-performance relationship, in the manner of Richard, Murthi, and Ismai (2007) and Ali, Kulik, and Metz (2011). In addition we explore the way in which these relationships are facilitated by an inclusive diversity culture, which some scholars have emphasized is necessary for firms to benefit from diversity (Richard et al. 2002; Dwyer et al. 2003; Pless and Maak 2004).

\section{THE FEMALE WORKFORCE AND CULTURE IN JAPAN}

In recent years the IMF has focused on how the aging population and shrinking labor force caused by low birth rates are depressing Japan's potential growth rate (Kingston 2013). In a report titled "Can Women Save Japan?" the IMF argued that increasing the female workforce, especially in career-track jobs, could boost economic growth. However, it is not so easy to overcome the current situation in Japan. First, only 12 percent of new hires are for career-track positions. Second, almost $68 \%$ of women drop out of the workforce upon having their first child due to several reasons, such as inadequate childcare support, their husband's long working hours, and inflexible employment policies. In a 2010 survey of Japanese women by the Ministry of Internal Affairs and Communication, 34 percent of respondents cited housework and 14 percent working hours as the primary reason they were not participating in the workforce.

Japanese companies' decision makers perceive female employees to be a significant handicap. Many senior executives expect that women will leave the company to raise their children. Thus women are seldom promoted, discouraging them and sapping their career motivation, despite the fact that the female workforce in Japan is the most educated in the world (OECD 2006). Strikingly, 74 percent of college-educated women quit their jobs voluntarily, more than double the rate in the United States (31\%) and Germany (35\%).

Yamaguchi $(2008,2011)$ has proposed precisely this form of statistical discrimination (in contradistinction to earlier Japanese researchers, such as Koike (1991) and Yashiro (1980), who tended to favor Phelps-type theories ${ }^{2}$ as the main cause of the low rates of women managerial participation in Japan, where there is much societal pressure onwomen to exit the labor force after childbirth, leading to higher

\footnotetext{
${ }^{2}$ A form of so-called statistical discrimination, first described by Phelps (1972), which can lead to inequitable buton average efficient personnel decisions.
} 
turnover and costs associated with women employees. However, the mechanism that he posits translates increased participation into higher productivity is that of the role model/motivational effect to be discussed below (Yamaguchi 2012).

As Staley (2002) notes, in traditional Japanese social culture women are expected to care for the family and assume domestic responsibilities, and some researchers identify this as the reason why companies do not recruit women for managerial positions. While Japanese culture is undergoing a transformation, it is still difficult to replace outdated but deeply rooted traditional managerial habits, such as seniority-based promotion, lifetime employment, paternalism, or prioritizing corporate harmony, which favor men (Vaszkun 2013).

However, more female participation in the workforce represents one feasible solution to the challenges confronting the Japanese economy. Facing pressure from foreign competition and a looming domestic labor shortage, Japanese companies in attempting to grapple with these new realities are undergoing organizational transformation. The growing importance of the female workforce under global competition requires a better understanding of gender-related issues in organizational management (Worthley et al. 2009).

\section{THEORETICAL FRAMEWORK}

\section{Positive Effects of Gender Diversity on Organizational Performance}

A number of researchers have proposed various mechanisms that would imply a positive relation between workforce diversity and firm performance. Moreover gender diversity has attracted the attention of researchers, politicians, and corporate executives around the world, especially on the question of how female representation in firms affects organizational and firm performance.

Laboratory studies of cultural diversity, including gender diversity, have generally yielded that the effectiveness of workgroups is enhanced by group-member diversity (Cox and Blake 1991). More heterogeneous groups tend to have broader knowledge and experience, analyze issues from a wider range of perspectives, and thus consider and debate a larger set of proposals, producing higher-quality and more innovative solutions (Hoffman and Maier 1961; DiTomaso, Post, and Parks-Yancy 2007). Gender diversity in particular has been found to enhance employees' overall creativity and innovation because of the combination of different skills, perspectives and backgrounds that men and women tend to possess (Egan 2005; Rogelberg and Rumery 1996). Moreover, women may provide more insight into the needs of female customers (Daily, Certo, and Dalton 1999; Nkomo and Cox 1996). These benefits of improved problemsolving, creativity, innovation, and market insight are valuable, rare, inimitable, and non-substitutable resources (Robinson and Dechant 1997) and thus, according to the resource-based view of the firm (Barney 1991), can produce a sustained corporate competitive advantage. Conversely, at the individual level, tokenism may impede the performance of members of a minority group when they are relatively few in number (Kanter 1977). Empirical studies conducted by Frink et al. (2003) have supported these positive views of diversity, even going so far as to suggest that an organization's optimal performance is achieved at maximum gender diversity (50\% women).

Herring (2009) points out that diversity pays by providing a competitive advantage through social complexity at the firm level, although such differences may lead to communication barriers and group conflict, and links diversity to profitability because businesses that draw on more inclusive talent pools are more successful.

We propose the following hypothesis:

Hypothesis 1a: Organizational gender diversity will be positively related to organizational performance. 


\section{NONLINEAR EFFECTS OF INCREASING GENDER DIVERSITY}

In addition to these positive effects there are possible negative effects as well. Moreover, the above positive associations are not necessarily linear - most effects may have diminishing returns where the additional profit from higher managerial gender diversity is smaller with increasing diversity. Thus the net combined relation between managerial gender diversity and firm performance should be curvilinear, specifically, concave (i.e., an inverted U-shape), with positive slope at low levels of managerial gender diversity and smaller positive or even negative slope as managerial gender diversity approaches its maximum.

Social identity, self-categorization, and similarity-attraction theories imply that diversity can be disadvantageous for organizations. According to these theories, individuals tend to be attracted to others whom they perceive to fall within the same social categories (Tajfel and Turner 1986; Turner, Hogg, Oakes, Reicher, and Wetherell 1987; Ashforth and Mael 1989; Mannix and Neale 2005), with gender being a prominent component of self-categorization. Moreover, they usually perceive their group to be superior to others. Thus diverse groups may fragment into smaller gender-homogeneous groups, with concomitant intergroup communication and cooperation difficulties, tensions, and even outright conflicts (Kravitz 2003; .Chatman and Flynn 2001; Pelled 1996). Empirical studies (e.g., Earley and Mosakowski 2000; Shapcott, Carron, Burke, Bradshaw, and Estabrooks 2006) have demonstrated these drawbacks as well. Not surprisingly, these negative effects have a deleterious impact on group and individual performance (Richard, McMillan, Chadwick, and Dwyer 2003).

This impairment is considerably stronger at higher levels of gender diversity, as the two groups approach each other in size, leading to potential power struggles (Blalock 1967). Meanwhile, the advantages of diversity, being primarily generated by the introduction of new perspectives and backgrounds, would tend to increase more slowly as the number of members in the minority group increase, the additional contribution to the group from minority-specific novelty having been already largely captured by the earliest minority members. The combination of these two conclusions yields a relationship between changes in gender diversity and organizational performance that is initially positive but then decreases and turns negative at high levels of diversity, which has been borne out in practice (Richard, Kochan, and McMillan-Capehart 2002; Knouse and Dansby 1999; Ali, Kulik, and Metz 2011). Nakagawa and Schreiber (2014) find, in the case of managers, that these relationships exhibit negative curvature, with diminishing returns to higher gender diversity.

We propose the following additionalhypothesis:

Hypothesis 1b: Organizational gender diversity will have an inverted U-shaped relationship with organizational performance.

\section{MODERATING EFFECTS OF INDUSTRY TYPE}

Recent research has emphasized the practical value of effective diversity management. Customer satisfaction is an important effectiveness metric for service organizations and is a key differentiator between firms in competitive industries such as retail (Jones and Sasser 1995). In addition, a significant relationship exists between customer satisfaction and company profitability (Gupta and Zeithaml 2006). The simultaneous production and consumption of services means that services operations have considerably more customer involvement than manufacturing operations (Batt 2000). Richard (2007) finds that, compared to manufacturing firms, services firms require more marketing insight, such as a cultural knowledge of market segments. Furthermore, Richard et al. (2013) assert that the services industries are best positioned to capitalize on the benefits of gender diversity due to the greater value of market insight to, and greater interaction among employees in firms of those industries.

By contrast, Siegel and Kodama (2011) used a dichotomous classification of companies as manufacturing or services and showed that in Japan manufacturing firms in particular have benefited from hiring female executives and female managers, and that a significant part of the benefit may derive from cost savings. 
Ali et al. (2011) found that, for Australian firms, the U-shaped gender diversity-performance relationship was stronger in services organizations than for manufacturing organizations, which they posited was due to the increased importance of customer involvement for service operations coupled with the ability of a gender-diverse workforce to facilitate effective interactions with both male and female customers.

\section{Moderating Effects of Reducing Overtime Hours}

Simpson (1998) discusses "presenteeism," as the tendency to stay at work beyond the time needed for effective performance of the job to demonstrate visible commitment in male-dominated organizations. Managers compete over who stays longest in the office to obtain promotion opportunities. This system attaches heavy costs to attempts to achieve work/life balance, especially for women who are raising children. Steinberg and Nakane (2012) point out that the difficulties of this balancing act are reflected in the sharp drop-off in labor participation rates of women in their late twenties and early thirties. This is particularly true in Japan, even though its labor participation rate for women at the start of their careers is as high as in comparable countries.

Golden (2011) observes that 'first, in terms of the volume (quantity) of working hours,...manufacturing productivity does not necessarily increase when hours are lengthened, and that in many industries, it appears that shorter hours are associated with higher output rates per hour. Second, in terms of work schedules, [there are] two separate categories of "flexible" working time arrangements that can have positive effects on enterprise performance: "Those [arrangements] that enhance individual or organizational productivity, and thus directly restrain unit labour costs of production; and those that improve employee health and well-being and satisfaction with the job or life, without raising current labour costs, and thus [result in] a long-run suppression of labour costs, to the extent that it saves the relatively more hidden costs associated with job dissatisfaction and human capital investment." Thus, firms' efforts to reduce overtime hours and inflexible environments eventually yield a positive impact on firm performance through enhanced individual and organizational productivity and reduction in unnecessary labour costs, but moreover will improve the job satisfaction and commitment-associated human capital investment of employees, especially women raising children.

Yamaguchi (2014) analyzes gender inequality in the proportion of managers in Japan and shows that it is less likely for college-graduate female employees to be promoted to manager than male employees with only a high school education, even when they have the same duration of employment. In addition, female employees are required to work longer hours than male employees to be promoted to managerial positions. This practice places a heavy burden on female employees who have children and domestic roles.

Therefore, to the extent that firms prioritize meritocracy over presenteeism, one indication of which is the average amount of overtime per employee, and implement work-life balance and family friendly policies, female employees could enjoy more promotion opportunities and thus may be more motivated and committed to the organization, increasing their productivity, as pointed out by Pfeffer (1981).

\section{MODERATING EFFECTS OF INCLUSIVENESS}

Social and cultural homogeneity and exclusiveness among the Japanese workforce have been discussed by many authors. Even Western researchers agree that people are more attracted to those who share similar attitudes (Byrne 1971) and surface-level demographic characteristics (Berscheud 1985) as themselves.

Holien (2013) summarizes studies that show that interacting with diverse others can be difficult and unpleasant and in particular that interactions with someone of different gender and race are associated with increases in negative emotions.

Most Western authors agree that the relation between diversity, HRM and performance is complex and remains unclear (Shaw and Barrett-Power 1998). However, Benschop (2001) finds that "an organization's strategy for managing diversity influences both the process of meaning-formation regarding diversity and perception of performance effects." 
Pless and Maak (2004) discuss a culture of inclusiveness in an organizational environment that allows people with multiple backgrounds, mindsets and ways of thinking to work effectively together and to perform to their highest potential in order to achieve organizational objectives based on sound principles. They focus on the challenge of building an inclusive diversity culture, showing that a "culture of inclusion" has to be built on solid moral grounds. They find the fact that, as diversity is essentially about cultural norms and values, appropriate "reflection work" is required to create a truly inclusive work environment where people from diverse backgrounds feel respected and recognized.

Shore et al. (2011) reviewed previous research and constructed a model of how inclusive work groups and their antecedent conditions create greater equality and opportunities in the workplace for diverse people by affirming the unique contributions they offer and encouraging full participation in work group activities. Richard et al. (2013) offered implications that inclusiveness in diverse groups can help an organization to avoid potential diversity pitfalls and obtain a superior diversity advantage. This study investigates how culture of inclusiveness may interact with gender diversity to influence organizational performance. This insight presents the potential for Japanese companies to shed light on the potential benefits by understanding this important segment of the workforce.

Thus we have:

Hypothesis 2a: Industry type moderates the gender diversity-performance relationship such that positive effects of gender diversity are stronger for firms in serviceindustries.

Hypothesis 2b: Overtime hours moderate the gender diversity-performance relationship in such a way as to decrease the positive effects of genderdiversity.

Hypothesis 2c: Inclusiveness moderates the gender diversity-performance relationship in such a way as to increase the positive effects of genderdiversity.

A possible framework is presented in Figure 1.

\begin{tabular}{l|lll}
$\begin{array}{l}\text { MODERATOR(+) } \\
\text { Industry type } \\
\text { Overtime hours } \\
\text { Inclusiveness }\end{array}$ & $\begin{array}{l}\mathrm{H} 2 \mathrm{a} \\
\mathrm{H} 2 \mathrm{~b}(-)\end{array}$ & Services $(+)$ & Manufacturing(-) \\
$\mathrm{H} 2 \mathrm{c}(+)$ & & \\
Gender Diversity & H1a & H1b (+ $\cap)$ & Firm Performance
\end{tabular}

Figure 1. Proposed Model of Industry Type, Inclusiveness, Gender Diversity, and Performance Cf. Ali et al. (2011)

\section{SAMPLE AND DATA}

\section{Research Design}

Our sample includes 745 Japanese listed companies contained in the CSR data of Toyo Keizai for both the period 2005-6 (out of 1082 firms) and the period 2011-12 (out of 1127 firms). This source provided data on the numbers of regular employees, regular female employees, and female and male managers, overtime hours, and intra-company diversity promotion organizations. Data on Tobin's q ${ }^{3}$, in 2005, 2011, and 2012, which is our measure of firm performance, are from Bloomberg, published in 2013.

\footnotetext{
${ }^{3}$ Tobin's q, the ratio of the market value of the firm to the replacement value of the firm's assets, is "widely viewed as the best measure of a firm's market value" (Dobbin and Jung 2011).
} 
The choice of 2005 as the initial data point for gender diversity allows a maximum time lag of 6 years between diversity and performance using longitudinal data. The 2012 final data point for gender diversity is chosen because it provided a minimum time lag of 9 months between diversity and performance (cf. below). The two time lags enable us to investigate whether gender diversity takes 1 or 6 years to impact firm performance.

\section{Outcome (Dependent Variable)}

\section{MEASURES}

In keeping with common practice in corporate governance research, Tobin's $q$ is utilized as a measure of firm performance.

\section{Predictor}

As a measure of managerial gender diversity, we use the female manager ratio, i.e., the proportion of all managers who are women, calculated for 2012 and 2006. The ratio from 2006 is also tested because of the possibility that there might be a time lag, of several years, in the effect of changes in the structure of management on firm performance.

\section{Moderators}

The firms are categorized into manufacturing or services industry type based on the Global Industry Classification Standard. The contextual dummy variable Manufacturing is defined to be 1 for the following industrial sectors, when the entire sector is classified as manufacturing, and constituent industries, when it is not: the basic materials sector (including mining, chemicals, and forest products), the industrial sector (including construction, engineering, machinery, and aerospace and defense), the technology sector with the exception of software, the energy sector (distinct from utilities, which are counted among services), most consumer non-cyclicals (excluding only health care services and commercial services, while including agriculture and food and beverages), and the textile, apparel, auto manufacturing and parts, home building, furniture, and housewares industries within the consumer cyclicals sector. The remaining sectors and industries were classed as services, including the communications, finance, and utilities sectors in their entireties. This division corresponds to that in Ali, Kulik, and Metz (2011).

Inclusiveness is represented by a dummy variable for the existence of an intra-company diversity promotion committee or organization. This information, as well as that on average overtime hours worked per employee per month, is derived from Toyo Keizai's surveys from 2006 and 2012.

\section{Controls}

Firm size, defined as the natural logarithm of the total number of employees, is used as a control variable. Organization age is also included as it may have an impact on performance: Compared to old firms, new firms with less formalized structures may be better positioned to capitalize on the benefits of gender diversity such as creativity and innovation.

Tobin's q is based on year-ending $(31 \mathrm{Dec})$ data, while sales revenue covers the full Japanese business year (which ends 31 Mar), whereas data on employees is as of 31 Mar. Thus, for example, Tobin's q for 2012 is as of 31 Dec 2012, the number of employees or female managers for 2012 is as of 31 Mar 2012, and the sales revenue for 2012 covers the period from 1 Apr 2012 to 31 Mar 2012. 


\section{METHODOLOGY AND MODELS}

\section{Hierarchical Multiple Regression Analysis}

These models are used in this study to explain how and to what extent firm financial performance is affected by gender diversity of the managers, along with the control variables. The fundamental models tested via hierarchical regression analysis are of the following form:

$$
\begin{aligned}
& \text { Performance }=\beta_{0}+\sum \beta_{i} x_{i}+\varepsilon \\
& \text { Performance }=\beta_{0}+\beta_{1} \text { Diversity }+\beta_{2} \text { Previous period }+\sum \beta_{i} x_{i}+\varepsilon \\
& \text { Performance } \left.=\beta_{0}+\beta_{1} \text { Diversity }+\beta_{2} \text { (Diversity }\right)^{2}+\beta_{3} \text { Previous period }+\sum \beta_{i} x_{i}+\varepsilon \\
& \text { Performance }= \\
& \left.\beta_{0}+\beta_{1} \text { Diversity }+\beta_{2} \text { (Diversity }\right)^{2}+\beta_{3} \text { Previous period }+\beta_{4} \text { Diversity } * \text { Moderator }+ \\
& \beta_{5}(\text { Diversity })^{2} * \text { Moderator }+\beta_{6} \text { Moderator }+\sum \beta_{i} x_{i}+\varepsilon
\end{aligned}
$$

where $x_{i}$ are the control variables listed above, which are the same for every model and submodel, Performance is Tobin's q in 2012, and Previous period is the same performance measure from 2006.

Each equation is tested for 2 different choices of explanatory variable Diversity: female manager ratio in 2012 and in 2006.

\section{RESULTS}

Table 1 displays the means, the standard deviations, and the number of firms. Table 2 presents the results of the correlation analyses for the 15 variables.

We used hierarchical multiple regression to test all hypotheses, similarly to the methodology of Ali et al. (2011). To test hypothesis 1A, firm performance (Tobin's q) in 2012 is regressed separately on each predictor (manager gender diversity in 2006 and 2012) after the relevant control variables for firm size and age are included (Model B). The results support the hypothesis for Tobin's q for the shorter time lag ( 9 months), but not for productivity or the longer 6-year time lag. Firm age and size were largely irrelevant after controlling for previous-period performance.

Hypothesis $1 \mathrm{~B}$, on the curvature of the relationship between gender diversity and performance, is not supported by any of the analyses (ModelC).

The test of hypothesis $2 \mathrm{~A}$ on the moderating effect of industry type yielded strong results, more so with a shorter lag, but in the opposite direction of that hypothesized. Manufacturing firms were found to significantly benefit to a greater extent from increasing gender diversity in management as compared to those in the service industries, and moreover the curvature of the relationship was also significantly higher for manufacturers. This is the opposite result to that found by Ali et al. for Australian firms, but accords with Siegel and Kodama's (2011) conclusion that manufacturing companies in Japan systematically profit from increasing their numbers of female executives and upper-middle managers generally, but even more so from the addition of their first such female manager, as compared to services companies, which have been utilizing female managers for a longer time and thus do not experience a significant impact on competitive advantage through an increase in their employment. Thus manufacturers show a greater sensitivity to gender diversity, benefitting more from beginning to employ female managers, but also with more rapid deceleration of the effect as their numbers increase. 
The results of the test of Hypothesis $2 \mathrm{~B}$ on the moderating effect of overtime hours were not as remarkable, but still were significant, particularly for the shorter time lag. The fewer average hours of overtime worked per employee the more firms were found to benefit from increasing gender diversity in management with the magnitude of the negative curvature of this relationship also being inversely proportional to the amount of overtime.

Similarly, the results of the analysis of Model D provide support for hypothesis 2C on the moderating effect of having an organization for promoting diversity, but only for the longer time lag. Firms with such a diversity committee in place for 5 years or more show a greater sensitivity to gender diversity, benefitting more from increasing the employment of female managers, but also with more rapid deceleration of the effect as their numbers increase.

\section{CONCLUSION}

This study has been conducted in Japan, where there is a scarcity of studies on the impact on firm performance of managerial gender diversity. In contrast, most western studies have focused on diversity of board members or employees and have been conducted in countries with much higher rates of female managerial participation than Japan.

After controlling for firm size and age, we find statistically a significant positive relationship between managerial gender diversity and one measure of firm performance, Tobin's q, without a long time lag required for it to be realized. Furthermore, we do not find that this relationship exhibits significant curvature, with or without a time lag. Thus our results in this regard do not resemble those of Richard et al. (2007) in the United States or Ali et al. (2011) in Australia.

We also find, similarly to Siegel and Kodama (2011), that manufacturing firms benefit to a greater extent from increasing managerial gender diversity as compared to those in the service industries, and moreover the curvature of this relationship is significantly greater for manufacturers. That is, our results show a stronger and more sensitive U-shaped relationship between managerial gender diversity and Tobin's q for manufacturers. Paradoxically, because female managers are underutilized at manufacturing firms relative to services firms, pioneering manufacturers can enjoy direct costs savings from the gender salary differential (Yamamoto and Matsuura 2014).

Furthermore, firms that demand fewer hours of overtime by their employees also experience this performance boost with increases in management gender diversity, with the same concave shape, and the more OT is reduced the more pronounced is the effect. This dovetails with Yamamoto and Matsuura's (2014) conclusion that employees, regardless of gender, can best demonstrate their hidden potential abilities at workplaces following WLB policies and where there are many more mid-career hires. If firms can assign the appropriate person, regardless of gender, to the right position, eventually organizational productivity will improve and hence firm performance.

Having established a committee for diversity promotion by 2006 did not show any impact on firm performance per se, even by 2012, but it did magnify the effect of gender diversity on Tobin's q, providing support for Pless and Maak's (2004) conjecture that a culture of inclusiveness is required for the benefits accruing to gender diversity to truly be realized. Thus establishing such a corporate culture would appear to be a necessary first step for a Japanese firm to reap the potential rewards of a more diverse management.

Among the limitations of this study is that for most companies the proportion of women managers was so low, averaging under $4 \%$, that extrapolating to very high levels of diversity, where the negative quadratic effects may become significant, is difficult. Also the data used in this paper include only firms listed for both the periods 2005-2006 and 2011-2013. Future studies should consider both intermediate and long-term performance to better understand the effects of diversity. 
This research is unique because it presents empirical evidence testing whether increasing gender diversity is associated with improved firm performance for Japanese listed companies, which have different cultural backgrounds from Western companies, after controlling for size and firm age. We examined the curvature of these relationships to estimate the moderating effect of industry type and inclusiveness workforce on the gender diversity-performance relationship.

We offer new, robust evidence for a linkage between Japanese firm performance and women's managerial participation. Gender diversity could revitalize Japanese firms by providing an immediately accessible but underutilized source of competitive advantage.

\section{AUTHOR INFORMATION}

Yukiko Nakagawa is a Global Human Resources General Manager at a Japanese multinational company, visiting lecturer at Hosei University in the Career Design Management, and PhD candidate at Keio University. She has coauthored four books on management: Management of Stakeholders, Irrational Management, Lessons on Management Philosophy, and Resilient Management. She is also co-author of Women As Drivers Of Japanese Firms' Success: The Effect Of Women Managers And Gender Diversity On Firm Performance, JDM Vol. 9, 2014. She is a researcher at the Keio Economic Observatory and visiting researcher at the Institute for Transnational Human Resource Management at Waseda University.

E-mail: snow_child10@hotmail.com (Corresponding author)

\section{REFERENCES}

Ali, Muhammed, Carol T. Kulik, and Isabel Metz. (2011). The gender diversity -performance relationship in services and manufacturing organizations.

International Journal of Human Resource Management, 22(7): 1464-85.

Arrow, Kenneth. (1973). The theory of discrimination. In Orley Ashenfelter and Albert Rees (Eds.), Discrimination in Labor Markets, pp. 3-33. Princeton, NJ: Princeton University Press.

Ashforth, Blake E., and Fred Mael. (1989). Social identity theory and the organization. Academy of Management Review, 14: 20-39

Barney, Jay B. (1986). Organizational culture: Can it be a source of sustained competitive advantage? Academy of Management Review, 11(3): 656-65. Barney, Jay B. (1991). Firm resources and sustained competitive advantage. Journal of Management, 17(1):99-120.

Barrett, Kelly. (2004). Women in the workplace: Sexual discrimination in Japan. Human Rights Brief, 11(2): 5-8

Bassman, Robert L. (1957). A generalized classical method of linear estimation of coefficients in a structural model. Econometrica, 25: 77-83.

Batt, Rosemary. (2000). Strategic Segmentation in Front-Line Services: Matching Customers, Employees and Human Resource Systems. International Jounral of Human Resource Management, 11:540-61.

Becker, Gary. (1971). The Economics of Discrimination, 2d ed. Chicago: University of Chicago Press.

Benschop, Yvonne. (2001). Pride, prejudice and performance: Relations between HRM, diversity and performance. Human Resource Management, 12(7): 1166-81.

Berscheid, Ellen S. (1985). Interpersonal attraction. In Gardner Lindzey and Elliot Aronson (Eds.), Handbook of Social Psychology, 3d ed., pp. 413-84. New York: Random House.

Blalock, Hubert M. (1967). Toward a Theory of Minority-Group Relations. New York: Wiley.

Blau, Peter Michael. (1977). Inequality and Heterogeneity: A Primitive Theory of Social Structure. New York: Free Press. Byrne, Donn. (1971). The Attraction Paradigm. New York: Academic Press.

Chatman, Jennifer A., and Francis J. Flynn. (2001). The influence of demographic heterogeneity on the emergence and consequences of competitive norms in work teams. Academy of Management Journal, 44: 956-74.

Cox, Taylor H., and Stacy Blake. (1991). Managing cultural diversity: Implications for organizational competitiveness. Academy of Management Executive,

5(3): 45-54.

Daily, Catherine M., S. Trevis Certo, and Dan R. Dalton. (1999). A decade of corporate women: Some progress in the boardroom, none in the executive suite. Strategic Management Journal, 20(1): 93-9.

Dezso, Christian L., and David G. Ross. (2012). Does female representation in top management improve firm 
performance? A panel data investigation.

Strategic Management Journal, 33(9): 1072-89.

DiTomaso, Nancy, Corinne Post, and Rochelle Parks-Yancy. (2007). Workforce diversity and inequality: Power, status, and numbers. Annual Review of Sociology, 33: 473-501.33:473-501.

Dobbin, Frank, and Jiwook Jung. (2011). Corporate board gender diversity and stock performance: The competence gap or institutional investor bias? North Carolina Law Review, 89(3): 809-38.

Earley, P. Christopher, and Elaine Mosakowski. (2000). Creating hybrid team cultures: An empirical test of transnational team functioning. Academy of

Management Journal, 43:26-49.

Egan, Toby Marshall. (2005). Creativity in the context of team diversity: Team leader perspective. Advances in Developing Human Resources, 7: 207-25. Frink, Dwight D., Robert K. Robinson, Brian Reithel, Michelle M. Arthur, Anthony P. Ammeter, Gerald R. Ferris, David M. Kaplan, and Hubert S.

Morrisette. (2003). Gender demography and organizational performance: A two-study investigation with convergence. Group \& Organization Management, 28: 127-47.

Golden, Lonnie. (2011). The Effects of Working Time on Productivity and Firm Performance: A Research Synthesis Paper. Conditions of Work and Employment Series, no. 33. Geneva: International Labour Office.

Gupta, Sunil, and Valerie Zeuthaml. (2006). Customer metrics and their impact on financial performance. Marketing Sci, 25(6): 718-39.

Hausmann, Ricardo, Laura D. Tyson, Yasmina Bekhouche, and Saadia Zahidi. (2013). The Global Gender Gap Report 2013. World Economic Forum.

Accessed at http://www3.weforum.org/docs/WEF_GenderGap_Report_2013.pdf

Herring, Cedric. (2009). Does diversity pay? Race, gender, and the business case for diversity. American Sociological Review, 74(2): 208-24.

Hoffman, L. Richard, and Norman R. F. Maier.(1961). Quality and acceptance of problem solutions by members of homogeneous and heterogeneous groups.

Journal of Abnormal and Social Psychology, 62(2): 401-7.

Holoien,Deborah.(2013). Do Differences Make a Difference? The Effects of Diversity on Learning, Intergroup Outcomes, and Civic Engagement.

www/Princeton.edu/reports/2013/diversity. 1-18.

Jones, Thomas O., and W. Earl Sasser, Jr. (1995). Why satisfied customers defect. Harvard Business Review, 73(Nov/Dec): 88-99. Kanter, Rosabeth Moss. (1977). Men and Women of the Corporation. New York: Basic Books.

Kingston, Jeff.(2013). Saving Japan: promoting women's role in the workforce would help. Japan Times, April $13^{\text {th. }} 2013$.

Knouse, Stephen B., and Mickey R. Dansby. (1999). Percentage of work-group diversity and work-group effectiveness. Journal of Psychology, 133: 486-94. Kodama, Naomi, Odaki, Kazuhiko and Takahashi, Yoko. (2005). Josei koyo to kigyo gyoseki [Female employment and corporate performance]. JCER

Economic Journal, no. 52: 1-18.

Kodama, Naomi, Odaki, Kazuhiko and Takahashi, Yoko. (2009). Why does employing more females increase corporate profits? Evidence from Japanese panel data. Japan Labor Review, 6(1):51-71.

Koike, Kazuo. (1991). Shigoto no Keizaigaku [Job economics]. Tokyo: Toyo Keizai.

Kravitz, David A. (2003). More women in the workplace: Is there a payoff in firm performance? Academy of Management Executive, 42: 3-21. Mannix, Elizabeth, and Margaret A. Neale. (2005). What differences make a difference? The promise and reality of diverse teams in organizations.

Psychological Science in the Public Interest, 6(2): 31-55.

Marikkar, Fatima Azmiah. (2007). The role of gender equality in the workplace in Japan. Kokusai Keiei Ronshu, 33 : 91-101.

Nakagawa, Yukiko, and Schreiber, G. M. (2014). Women as drivers of Japanese firms' success: The effect of women managers and gender diversity on firm performance. Journal of Diversity Management, 9(1): 1-21.

Nkomo, Stella M., and Taylor Cox Jr. (1996). Diverse identities in organizations. In Stewart R. Clegg, Cynthia Hardy, and Walter R. Nord (Eds.), Handbook

of Organization Studies, pp. 338-56. London: Sage.

OECD. (2006). Education at a Glance. OECD Indicators 2006, Paris.

OECD. (2012). Closing the Gender Gap. Act Now. OECD Publishing. Accessed at 
http://dx.doi.org/10.1787/9789264179370-en

Pelled, Lisa Hope. (1996). Demographic diversity, conflict, and work group outcomes: An intervention process theory. Organization Science, 7: 615-31. Phelps, Edmund S. (1972). The statistical theory of racism and sexism. American Economic Review, 62: 659-61.

Pfeffer, Jeffrey. (1981). Management as symbolic action: The creation and maintenance of organizational paradigms. Research in Organizational Behavior, 3: 1-52.

Pfeffer, Jeffrey. (1994). Competitive Advantage through People. Boston, MA: Harvard Business School Press.

Pless, Nicola M., and Maak, Thomas. (2004). Building an Inclusive Diversity Culture; Principals, Processes and Practice. Journal of Business Ethics,

54:129-47.

Richard, Orlando C., Thomas A. Kochan, and Amy McMillan-Capehart. (2002). The impact of visible diversity on organizational effectiveness: Disclosing the contents in Pandora's black box. Journal of Business and Management, 8: 265-91.

Richard, Orlando C., Tim Barnett, Sean Dwyer, and Ken Chadwick. (2004). Cultural diversity in management, firm performance, and the moderating role of entrepreneurial orientation dimensions. Academy of Management Journal, 47(2): 255-66.

Richard, Orlando C., B. P. S. Murthi, and Kiran Ismail. (2007). The impact of racial diversity on intermediate and long-term performance: The moderating role of environmental context. Strategic Management Journal, 28: 1213-33

Richard, Orlando C., Susan L.Kirby, and Ken Chadwick. (2013). The impact of racial and gender diversity in management on financial performance: How participative strategy making features can unleash a diversity advantage. International Journal of Human Resource Management, 24(13): 2571-82

Robinson, Gail, and Kathleen Dechant. (1997). Building a business case for diversity. Academy of Management Executive, 11(3): 21-31.

Rogelberg, Steven G., and Steven M. Rumery. (1996). Gender diversity, team decision quality, time on task, and interpersonal cohesion. Small Group Research, 27: 79-90.

Rosen, Benson, Mabel Miguel, and Ellen Peirce. (1989). Stemming the exodus of women managers. Human Resource Management, 28: 475-91.

Shapcott, Kim M., Albert V. Carron, Shauna M. Burke, Michael H. Bradshaw, and Paul A. Estabrooks. (2006). Member diversity and cohesion and performance in working groups. Small Group Research, 37: 701-20.

Shaw, James B., and Elain Barett-Power. (1998). The effects of diversity on small work group processes and performance. Human Relations, 51: 1307-25.

Shore, L.M., Randel, A.E., Chung, B.G., Dean, M.A., Ehrhart, K.H., and Singh, G. (2011). Inclusion and Diversity in Work Groups: A Review and Model for Future Research, Journal of Management, 37, 1262-1289.

Siegel, Jordan, and Kodama, Naomi. (2011). Labor market gender disparity and corporate performance in Japan. RIETI Discussion Paper Series 11-E-075. Simons, George F., Carmen Vazquez, and Philip R. Harris. (1993). Transcultural Leadership: Empowering the Diverse Workforce. Managing Cultural

Differences Series. Houston, London and Tokyo: Gulf Publishing.

Simpson, R. (1998). Presenteeism, power and organizational change: Long hours as a career barrier and the impact on the working lives of women managers. British Academy of Management, 9: 37-50.

Staley, D.(2002). Japan's Uncertain Future. Futurist, March-April: 48-53.

Steinberg, C., and Nakane, M. (2012). Can Women Save Japan? IMF Working Paper 12/248. Washington: IMF.

Tajfel, Henri, and John C. Turner. (1986). The social identity theory of intergroup behavior. In Stephen Worschel and William G. Austin (Eds.), Psychology of Intergroup Relations, 2d ed.:. 7-24. Chicago: Nelson-Hall.

Trost, Cathy. (1989). Firms heed women employees' needs: New approach forced by shifts in population. Wall Street Journal, Nov 22: B1.

Turner, John C., Michael A. Hogg, Penelope J. Oakes, Stephen D. Reicher, and Margaret S. Wetherell (Eds.). (1987). Rediscovering the Social Group: A Self-Categorization Theory. Oxford:Blaisdell.

Wakisaka, Akira. (2001). Shigoto to katei no ryoritsu shien seido no bunseki: Joshi koyo kanri kihon chosa wo mochiite [Analysis of systems to support the balancing of work and family using the basic survey on women's employment management]. In Koyo keisaku no keizai bunseki [Economic analysis of employment policies], pp. 195-224. Tokyo: University of Tokyo Press.

Worthley, R., MacNab, B., Brislin, R.,Ito, K.,and Rose, E. L.(2009). Workforce motivation in Japan: and 
examination of gender differences and management perceptions. International Jounral of Human Resource Management, 20:7: 1503-1520.

Vaszkun, Balazs.(2013).Managers can also resist changes - Can we deal with this? An exploratory study from Japan. Journal of Enterprising Culture, Dec2013, 21-4.:447-493.

Yamaguchi, Kazuo. (2008). Strategies for elimination of gender inequality in wages: Theoretical and empirical bases for the economic irrationality of statistical discrimination. Japanese Journal of Labour Studies, 50: 40-68

Yamaguchi, Kazuo. (2011). Gender Equality and Economic Growth. Japan.REITI, Column 228. Accessed at http://www.rieti.go.jp/en/columns/a01_0333.html

Yamaguchi , Kazuo. (2012). Low Japanese female managers' ratio: Positive promotion causes improving productivity (in Japanese). Nihon Keizai Shimbun,Keizai Kyoshitsu column,July 16. English translation accessed at http://www.rieti.go.jp/en/papers/contribution/yamaguchi/06.html.

Yamamoto, Isao and Matsuura, Toshiyuki (2012). Effect of Work-Life Balance Practices on Firm Productivity: Evidence from Japanese firm-level panel data, RIETI Discussion Paper Series 12-E-079:1-33.

Yamamoto, Isao, and Matsuura, Toshiyuki (2014). Effect of Work-Life Balance Practices on Firm Productivity: Evidence from Japanese Firm-level Panel Data. B.E. Journal of Economic Analysis and Policy (forthcoming)

Yashiro, Naohiro. (1980). Male-female wage differentials in Japan: A rational explanation. Japanese Economic Studies, 3: 28-61. 


\section{APPENDIX}

Table 1. Descriptive Statistics

\begin{tabular}{lccc}
\hline \multicolumn{1}{c}{ Variable } & Mean & Standard Deviation & Number Of Firms \\
\hline Female manager ratio & 0.0366 & 0.0647 & 607 \\
Female manager ratio, 2006 & 0.0321 & 0.0623 & 669 \\
Firm age & 61.4242 & 24.4948 & 712 \\
Natural logarithm of number of employees & 7.1074 & 1.3887 & 751 \\
Industry type (1=Manufacturing; 0=Services) & 0.6352 & 0.4817 & 751 \\
Tobin Q & 0.9632 & 0.2618 & 692 \\
Tobin Q, 2011 & 0.9685 & 0.2772 & 696 \\
Tobin Q, 2005 & 1.2829 & 1.2233 & 661 \\
Sales revenue per employee & 220.2393 & 869.3492 & 700 \\
Sales revenue per employee, 2011 & 211.9586 & 795.2904 & 705 \\
Sales revenue per employee, 2005 & 214.506 & 924.5246 & 693 \\
Average monthly OT per employee per month & 18.2335 & 9.7158 & 535 \\
Average monthly OT per employee per month, 2006 & 21.752 & 10.2192 & 567 \\
Has diversity committee (dummy) & 0.2677 & 0.443 & 736 \\
Has diversity committee, 2006 (dummy) & 0.1991 & 0.3996 & 698 \\
\hline
\end{tabular}

Notes: All data are from 2012 unless otherwise indicated. Means for dummy variables are the proportion of firms with the given characteristic.

Table 2. Hierarchical Multiple Regression Analysis Estimate of Manager Gender Diversity in 2012 Predicting 2012 Firm Performance (Tobin's Q), as Moderated by Industry Type

\begin{tabular}{|c|c|c|c|c|}
\hline \multirow[b]{2}{*}{ Variable } & \multicolumn{4}{|c|}{ Model } \\
\hline & $\mathbf{1 A}$ & 1B & $2 \mathrm{C}$ & 2D \\
\hline Female manager ratio & & $0.044 * * *$ & 0.024 & $-0.173 * *$ \\
\hline Fem mgr ratio squared & & & & $0.179 * *$ \\
\hline Manufacturing dummy & & & & $-0.103 * * *$ \\
\hline Fem mgr ratio $\mathrm{x}$ manufacturing dummy & & & & $0.244 * * *$ \\
\hline Fem mgr ratio squared $\mathrm{x}$ manufacturing dummy & & & & -0.178 \\
\hline Tobin q, 2011 & $0.896 * * *$ & $0.889^{* * *}$ & $0.889 * * *$ & $0.889 * * *$ \\
\hline Firm age & $-0.028 *$ & -0.019 & -0.019 & -0.021 \\
\hline Log number employees & 0.013 & 0.017 & 0.018 & 0.018 \\
\hline$N$ & 732 & 732 & 732 & 732 \\
\hline Adjusted $R^{2}$ & 0.809 & 0.811 & 0.81 & 0.815 \\
\hline F-Statistic & $1030 * * *$ & $783 * * *$ & $626 * * *$ & $402 * * *$ \\
\hline$\ddot{\mathrm{A}} R^{2}$ & & 0.002 & 0.000 & 0.005 \\
\hline Incremental F-Statistic & & $6.935 * * *$ & 0.259 & $6.282 * * *$ \\
\hline
\end{tabular}

Notes: Regression coefficients are standardized (betas). The change in $R^{2}$ and incremental F-test reported for Models $\mathrm{B}, \mathrm{C}$, and D correspond to the differences between Models A and B, B and C, and C and D, respectively. Probability values are based on a t-statistic for a two-tailed test of significance, using White heteroscedasticity-consistent errors. * indicates $p<0.10$; ** indicates $p<0.05 ; * * *$ indicates $p<0.01$. 
Table 3. Hierarchical Multiple Regression Analysis Estimate of Manager Gender Diversity in 2012 Predicting 2012 Firm Performance (Tobin's Q), as Moderated by OT Hours

\begin{tabular}{|c|c|c|c|c|}
\hline \multirow[b]{2}{*}{ Variable } & \multicolumn{4}{|c|}{ Model } \\
\hline & $1 \mathrm{~A}$ & 1B & $1 \mathrm{C}$ & 1D \\
\hline Female manager ratio & & $0.042 * *$ & $0.077 * * *$ & $0.154 * * *$ \\
\hline Fem mgr ratio squared & & & $-0.042 * *$ & $-0.180 * * *$ \\
\hline OT hrs/month & & & & $0.039 *$ \\
\hline Fem mgr ratio $06 \times$ OT hrs & & & & $-0.128^{*}$ \\
\hline Fem mgr ratio 06 squared $\mathrm{x}$ OT hrs & & & & $0.166^{* *}$ \\
\hline Tobin Q, 2011 & $0.919 * * *$ & $0.914 * * *$ & $0.912 * * *$ & $0.915 * * *$ \\
\hline Firm age & $-0.029 *$ & -0.022 & -0.019 & -0.020 \\
\hline Log number employees & -0.006 & -0.001 & -0.001 & -0.004 \\
\hline$N$ & 625 & 625 & 625 & 625 \\
\hline Adjusted $R^{2}$ & 0.841 & 0.842 & 0.842 & 0.843 \\
\hline F-Statistic & $1100 * * *$ & $832 * * *$ & $668 * * *$ & $420 * * *$ \\
\hline $\mathrm{D} R^{2}$ & & 0.002 & 0.001 & 0.002 \\
\hline Incremental F-Statistic & & $6.675 * *$ & 2.343 & $2.116^{*}$ \\
\hline
\end{tabular}

Notes: Regression coefficients are standardized (betas). The change in $R^{2}$ and incremental F-test reported for Models $\mathrm{B}$, $\mathrm{C}$, and $\mathrm{D}$ correspond to the differences between Models $\mathrm{A}$ and $\mathrm{B}, \mathrm{B}$ and $\mathrm{C}$, and $\mathrm{C}$ and $\mathrm{D}$, respectively. Probability values are based on a t-statistic for a two-tailed test of significance, using White heteroscedasticity-consistent errors. ${ }^{*}$ indicates $p<0.10$; $* *$ indicates $p<0.05 ; * * *$ indicates $p<0.01$.

Table 4. Hierarchical Multiple Regression Analysis Estimate of Manager Gender Diversity in 2012 Predicting 2012 Firm Performance (Tobin's Q), as Moderated by Inclusiveness

\begin{tabular}{|c|c|c|c|c|}
\hline \multirow[b]{2}{*}{ Variable } & \multicolumn{4}{|c|}{ Model } \\
\hline & $\mathbf{1 A}$ & 1B & $1 \mathrm{C}$ & 1D \\
\hline Female manager ratio & & $0.044 * *$ & $0.059 *$ & 0.029 \\
\hline Fem mgr ratio squared & & & -0.018 & 0.004 \\
\hline Diversity comm dummy & & & & 0.025 \\
\hline Fem mgr ratio $\mathrm{x}$ diversity comm dummy & & & & 0.012 \\
\hline Fem mgr ratio squared $\mathrm{x}$ diversity comm dummy & & & & 0.018 \\
\hline Tobin Q, 2011 & $0.895 * * *$ & $0.890 * * *$ & $0.889 * * *$ & $0.887 * * *$ \\
\hline Firm age & $-0.029 *$ & -0.021 & -0.020 & -0.022 \\
\hline Log number employees & 0.012 & 0.015 & 0.016 & -0.001 \\
\hline$N$ & 728 & 728 & 728 & 728 \\
\hline Adjusted $R^{2}$ & 0.808 & 0.809 & 0.809 & 0.81 \\
\hline F-Statistic & $1020 * * *$ & $773 * * *$ & $618 * * *$ & $389 * * *$ \\
\hline $\mathrm{D} R^{2}$ & & 0.002 & 0.000 & 0.002 \\
\hline Incremental F-Statistic & & $6.876^{* * *}$ & 0.383 & 2.046 \\
\hline
\end{tabular}

Notes: Regression coefficients are standardized (betas). The change in $R^{2}$ and incremental F-test reported for Models $\mathrm{B}$, $\mathrm{C}$, and $\mathrm{D}$ correspond to the differences between Models A and B, B and C, and C and D, respectively. Probability values are based on a t-statistic for a two-tailed test of significance, using White heteroscedasticity-consistent errors. * indicates $p<0.10$; $* *$ indicates $p<0.05$; *** indicates $p<0.01$. 
Table 5. Hierarchical Multiple Regression Analysis Estimate of Manager Gender Diversity in 2006 Predicting 2012 Firm Performance (Tobin's Q), as Moderated by Industry Type

\begin{tabular}{|c|c|c|c|c|}
\hline \multirow[b]{2}{*}{ Variable } & \multicolumn{4}{|c|}{ Model } \\
\hline & $\mathbf{1 A}$ & 1B & $1 \mathrm{C}$ & 1D \\
\hline Female manager ratio 2006 & & 0.040 & 0.097 & 0.060 \\
\hline Fem mgr ratio 2006 squared & & & -0.064 & -0.027 \\
\hline Manufacturing dummy & & & & -0.031 \\
\hline Fem mgr ratio $2006 \times$ manufacturing dummy & & & & $0.193 * *$ \\
\hline Fem mgr ratio 2006 squared $\mathrm{x}$ manufacturing dummy & & & & $-0.193 * *$ \\
\hline Tobin Q, 2005 & $0.483 * * *$ & $0.479 * * *$ & $0.475 * * *$ & $0.474 * * *$ \\
\hline Firm age & -0.001 & 0.005 & 0.007 & 0.001 \\
\hline Log number employees & $0.242 * * *$ & $0.246^{* * *}$ & $0.248 * * *$ & $0.238 * * *$ \\
\hline$N$ & 562 & 562 & 562 & 562 \\
\hline Adjusted $R^{2}$ & 0.289 & 0.289 & 0.289 & 0.293 \\
\hline F-Statistic & $77.00 * * *$ & $58.00 * * *$ & $46.60 * * *$ & $30.10 * * *$ \\
\hline $\mathrm{D} R^{2}$ & & 0.002 & 0.001 & 0.008 \\
\hline Incremental F-Statistic & & 1.184 & 0.758 & $2.138 *$ \\
\hline
\end{tabular}

Table 6. Hierarchical Multiple Regression Analysis Estimate of Manager Gender Diversity in 2006 Predicting 2012 Firm Performance (Tobin's Q), as Moderated by OT Hours

\begin{tabular}{|c|c|c|c|c|}
\hline \multirow[b]{2}{*}{ Variable } & \multicolumn{4}{|c|}{ Model } \\
\hline & $\mathbf{1 A}$ & 1B & $1 \mathrm{C}$ & 1D \\
\hline Female manager ratio 2006 & & 0.039 & 0.052 & -0.107 \\
\hline Fem mgr ratio 2006 squared & & & -0.014 & 0.051 \\
\hline OT hrs/month, 2006 & & & & $-0.078^{*}$ \\
\hline Fem mgr ratio $06 \times$ OT hrs 2006 & & & & 0.160 \\
\hline Fem mgr ratio 06 squared x OT hrs 2006 & & & & -0.044 \\
\hline Tobin Q, 2005 & $0.505^{* * *}$ & $0.501^{* * *}$ & $0.500^{* * *}$ & $0.492^{* * *}$ \\
\hline Firm age & 0.030 & 0.035 & 0.036 & 0.030 \\
\hline Log number employees & $0.229^{* * *}$ & $0.233^{* * *}$ & $0.233^{* * *}$ & $0.240^{* * *}$ \\
\hline$N$ & 473 & 473 & 473 & 473 \\
\hline Adjusted $R^{2}$ & 0.304 & 0.304 & 0.302 & 0.303 \\
\hline F-Statistic & $69.60^{* * *}$ & $52.40^{* * *}$ & $41.90^{* * *}$ & $26.70^{* * *}$ \\
\hline $\mathrm{D} R^{2}$ & & 0.001 & 0 & 0.005 \\
\hline Incremental F-Statistic & & 0.970 & 0.032 & 1.182 \\
\hline
\end{tabular}


Table 7. Hierarchical Multiple Regression Analysis Estimate of Manager Gender Diversity in 2006 Predicting 2012 Firm Performance (Tobin's Q), as Moderated by Inclusiveness

\begin{tabular}{|c|c|c|c|c|}
\hline \multirow[b]{2}{*}{ Variable } & \multicolumn{4}{|c|}{ Model } \\
\hline & $\mathbf{1 A}$ & $1 \mathbf{B}$ & 1C & $1 \mathrm{D}$ \\
\hline Female manager ratio 2006 & & 0.045 & 0.104 & 0.102 \\
\hline Fem mgr ratio 2006 squared & & & -0.068 & -0.061 \\
\hline Diversity comm 2006 dummy & & & & -0.039 \\
\hline Fem mgr ratio $06 \mathrm{x}$ diversity comm 06 dummy & & & & $0.180 * *$ \\
\hline Fem mgr ratio 06 squared $\mathrm{x}$ diversity comm 06 dummy & & & & $-0.181 * * *$ \\
\hline Tobin Q, 2005 & $0.485 * * *$ & $0.481 * * *$ & $0.478 * * *$ & $0.476 * * *$ \\
\hline Firm age & -0.001 & 0.004 & 0.006 & 0.007 \\
\hline Log number employees & $0.238 * * *$ & $0.242 * * *$ & $0.244 * * *$ & $0.240 * * *$ \\
\hline$N$ & 551 & 551 & 551 & 551 \\
\hline Adjusted $R^{2}$ & 0.291 & 0.292 & 0.292 & 0.292 \\
\hline F-Statistic & $76.40 * * *$ & $57.70 * * *$ & $46.30 * * *$ & $29.40 * * *$ \\
\hline$\ddot{\mathrm{A}} R^{2}$ & & 0.002 & 0.001 & 0.004 \\
\hline Incremental F-Statistic & & 1.481 & 0.869 & 1.147 \\
\hline
\end{tabular}

Notes: Regression coefficients are standardized (betas). The change in $R^{2}$ and incremental F-test reported for Models $\mathrm{B}$, C, and D correspond to the differences between Models A and B, B and C, and C and D, respectively. Probability values are based on a t-statistic for a two-tailed test of significance, using White heteroscedasticity-consistent errors. * indicates $p<0.10 ; * *$ indicates $p<0.05 ; * * *$ indicates $p<0.01$. 
Table 8. Correlation Matrix Of All Variables

\begin{tabular}{|c|c|c|c|c|c|c|c|c|c|c|c|c|c|}
\hline Variable & 1 & 2 & 3 & 4 & 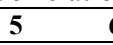 & 6 & 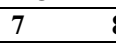 & 8 & 9 & 10 & 11 & 12 & 14 \\
\hline \multicolumn{14}{|l|}{$\begin{array}{l}1 \text { Female manager } \\
\text { ratio }\end{array}$} \\
\hline $\begin{array}{l}2 \text { Female manager } \\
\text { ratio, } 2006\end{array}$ & $0.862^{* * *}$ & & & & & & & & & & & & \\
\hline 3 Firm age & $-0.130^{* * *}$ & $-0.197^{* * *}$ & & & & & & & & & & & \\
\hline $\begin{array}{l}4 \text { Natural logarithm } \\
\text { of number of } \\
\text { employees }\end{array}$ & -0.031 & $-0.094^{* *}$ & $0.282^{* * *}$ & & & & & & & & & & \\
\hline $\begin{array}{l}5 \text { Industry type } \\
\text { (1=Manufacturing; } \\
0=\text { Services) }\end{array}$ & $-0.277^{* * *}$ & $-0.314^{* * *}$ & $0.261^{* * *}$ & $0.116^{* * *}$ & & & & & & & & & \\
\hline 6 Tobin Q & $0.103^{* *}$ & $0.081^{* *}$ & -0.029 & $0.251^{* * *}$ & -0.022 & & & & & & & & \\
\hline 7 Tobin Q, 2011 & 0.054 & 0.031 & 0.006 & $0.281^{* * *}$ & 0.020 & $0.915^{* * *}$ & & & & & & & \\
\hline 8 Tobin $\mathrm{Q}, 2005$ & $0.107^{* *}$ & $0.110^{* * *}$ & $-0.168^{* * *}$ & 0.008 & $-0.082^{* *}$ & ${ }^{*} 0.484^{* * *}$ & $0.568^{* * *}$ & & & & & & \\
\hline $\begin{array}{l}9 \text { Sales Revenue per } \\
\text { Employee }\end{array}$ & 0.049 & 0.026 & $-0.085^{* *}$ & $-0.101^{* * *}$ & ${ }^{*}-0.070^{*}$ & 0.021 & 0.016 & -0.016 & & & & & \\
\hline $\begin{array}{l}10 \text { Sales Revenue } \\
\text { per Employee, } 2011\end{array}$ & 0.049 & 0.023 & $-0.080^{* *}$ & $-0.098^{* * *}$ & ${ }^{*}-0.075^{* *}$ & * 0.018 & 0.018 & -0.018 & $0.996^{* * *}$ & & & & \\
\hline $\begin{array}{l}11 \text { Sales Revenue } \\
\text { per Employee, } 2005\end{array}$ & 0.062 & 0.028 & $-0.122^{* * *}$ & -0.028 & $-0.094^{* *}$ & * 0.008 & 0.008 & -0.018 & $0.846^{* * *}$ & $0.850^{* * *}$ & & & \\
\hline $\begin{array}{l}12 \text { Avg Monthly } \\
\text { OT, per employee }\end{array}$ & $-0.079^{*}$ & $-0.074^{*}$ & -0.049 & $0.169^{* * *}$ & 0.009 & $0.101^{* *}$ & $0.083^{*}$ & 0.073 & 0.005 & 0.012 & 0.060 & & \\
\hline $\begin{array}{c}13 \text { Avg Monthly } \\
\text { OT, per employee, } \\
2006 \\
\end{array}$ & -0.068 & $-0.105^{* *}$ & -0.032 & $0.088^{* *}$ & 0.042 & 0.033 & 0.037 & $0.106^{* *}$ & -0.011 & -0.005 & -0.013 & $0.750^{* * *}$ & \\
\hline $\begin{array}{l}14 \text { Has diversity } \\
\text { committee (dummy) }\end{array}$ & 0.034 & -0.027 & $0.144^{* * *}$ & $0.512^{* * *}$ & 0.000 & $0.149^{* * *}$ & $0.166^{* * *}$ & -0.014 & $0.102^{* * *}$ & $0.109^{* * *}$ & $0.132^{* * *}$ & 0.054 & -0.008 \\
\hline $\begin{array}{l}15 \text { Has diversity } \\
\text { committee, } 2006 \\
\text { (dummy) }\end{array}$ & 0.058 & 0.017 & $0.117^{* * *}$ & $0.428^{* * *}$ & -0.057 & $0.099^{* *}$ & $0.102^{* * *}$ & -0.017 & 0.010 & 0.016 & 0.048 & 0.002 & $-0.0150 .641^{* * *}$ \\
\hline
\end{tabular}

